\title{
LiKe Nobody Else: The Secrets of Metaphorical Style
}

\author{
(Como Ninguém mais: Os Segredos do Estilo Metafórico) \\ Dr. Jeannine M. FonTAINE, IUP \\ Dr. Joyce STavick, Truett-McConnell College
}

AвSTRACT: Metaphor is pervasive in literature, and metaphorical choices can be seen as central to what we call an author's 'style.' This study provides an illustrative overview, based on fifty-page prose excerpts from fourteen authors representing diverse genres and periods. Categorizing examples by frequency, syntactic form and meaning, a clear characteristic or combination of characteristics readily emerges for each novelist. Having covered these, we then look in more detail at the semantics of metaphor in Arundhati Roy's novel The God of Small Things. Finally, we hypothesize that an expanded study, considering the function of metaphors in text and their interre lationships, could yield an increasingly fine-grained measure of metaphorical style. KEY-WORDs: Stylistics; Metaphor; Discourse; Cognitive linguistics.

Resumo: A metáfora é uma constante na literatura, e escolbas metafóricas podem ser consideradas essenciais ao que chamamos do estilo do autor. Este estudo fornece uma revisão ilustrada, baseada em trechos de cinqüienta páginas, selecionadas de catorze autores que representam diversos gêneros e períodos. Quando categorizamos exemplos por frequiencia, forma sintática, e significado, facilmente emerge uma característica evidente, ou uma combinaçãa de características para cada autor. Nós então analisamos mais detalhadamente a semântica da metáfora no livro The God of Small Things, de Arundhati Roy. Finalmente, propomos que um estudo mais extensivo, considerando a função das metáforas e suas Inter-relações, pode resultar numa medida cada vez mais precisa do estilo metafórico.

PaLAVRas-ChaVe: Estilística; Metáfora; Discurso; Lingüística cognitiva.

\section{Introduction: Background Assumptions}

This paper builds on a set of assumptions about metaphor, some of which are set out in an earlier paper (Donna 2002). Basically, the idea is

D.E.L.T.A., 20:1, 2004 (49-75) 
that metaphorical language in literary and other creative texts is simply an extension of a linguistic way of life that researchers since Lakoff \& Johnson (1983) have so persuasively shown us is central to our use of language (cf. also Gibbs \& Steen, 1990). In fact, the process that creates metaphor is just one example of a pervasive pattern that operates in all linguistic and conceptual systems, producing lknks within and between areas as disparate as phonology, morphology, syntax and even gestural patterns, as proposed in Jackendoff (2002). In fact, it is striking that Jackendoff, whose main interest is in building a formal model of language, specifically singles out metaphor as a 'general process' deriving lexical meaning (2002: 343). Indeed, metaphor seems to be the rule (or at least one of them) in the lexicon, rather than the exception.

If this view is right, it should come as no surprise that we exploit this very basic and ubiquitous human linguistic tendency when we use language for creative ends (see, e.g., Lakoff \& Turner 1989; Steen 1994) - just as it requires no explanation that, as upright-walking bipedal primates, we use our legs to dance. It is a central tenet of our approach that, due to its special place in language itself, the kind of linking called 'metaphorical' should be given a privileged place among rhetorical figures in literary studies.

A few additional assumptions should be stated at the outset. First, we make no distinction between 'metaphor,' 'simile,' and 'implied metaphor,' since all three encompass the same kind of relationship between two elements being compared in some way, one typically literal (the 'tenor'), and thus part of the basic meaning of a text, the other often figurative or imagined (the 'vehicle'), intended to enrich the meaning of the literal. In fact, since what is traditionally termed 'personification' tends to accomplish a similar function (to suggest that some inanimate or abstract entity shares human features), we include examples that might traditionally be termed 'personification' in the scope of our term 'metaphor.'

\footnotetext{
1 Most definitions, while they diverge in details, agree that a metaphor is a way of 'seeing something in terms of something else' (Burke, cited in Cameron \& Low 1999: 13). Many current textbook treatments acknowledge that metaphor is often implied, rather than being expressed overtly in canonical forms using like (the 'simile' form) or some version of the copula. Thus, when Alison Lurie writes that Bougainvillea foamed over white stucco walls (1999: 22), she is implying, by her choice of the verb foam, a similarity between the flowers and a liquid capable of producing froth as it overflows its container. One need only look at parallel cases involving implied similarity to
} 
A second assumption is rooted in what has been termed 'forensic linguistics.' Practitioners in this small but fascinating field have found that one can trace virtually any text to its writer by looking closely at the quirks of style that it contains - that is, every writer will 'give herself away' by the kinds of structures and forms she tends to use. Don Foster of Vassar College has made something of a reputation for proving this claim, for instance when he discovered the identity of the anonymous writer of Primary Colors using features of style, lexis, and sentence structure (Roberts 2001; Foster 2000).

Our claim, a literary/creative cousin to Foster's, is quite simply stated: that individual authors use distinctive styles that can be spelled out precisely in a rigorous enough framework. In particular, we claim that a single feature can go a long way toward identifying a writer's typical form of expression, provided the feature in question is as rich as the set of rhetorical tricks we gather under the term 'metaphorical language.' In this study, we look at metaphorical style in prose fiction texts by focusing largely on frequency, clustering, form and semantic pairings; however, we acknowledge in our closing remarks that other features could be considered, and we suggest that a larger inventory of features should produce increasingly fine-grained stylistic portraits. Of course, the features we look at are often partially

humans, to see that there is no well-defined boundary between the kinds of phrases traditionally labeled as 'metaphor' and 'personification.' Consider, for instance, this quote from Thomas Hardy's lengthy 'personification' of Egdon heath, discussed later in this paper: the heath appeared slowly to awake and listen. Every night its Titanic form seemed to await something. (1995: 31). Here, the heath, a geographical entity, is said to resemble, or 'be like,' a person, in that its stirrings are like those of a person awaking, and its silence reminds the observer of a person awaiting some momentous event. Similarly, when Margaret Atwood says Jon's studio... doesn't have long to live in its present form. (1989: 16), she phrases the impending destruction or change in the studio 'in terms of the end of a person's life. The more canonical examples typically used to exemplfy personification also yield to the same reasoning; when death is personified in a literary work, presumably the intention is to imply that death has something in common with an intentional being who attacks or exerts power over humans. Our viewpoint, which sees commonality in these phenomena, is not entirely novel; one recent, widely used anthology defines personification as "a form of metaphor in which human characteristics are attributed to nonhuman things."(italics added) (Meyer, 1999: 2138). One final note: an interestingly problematic example comes with Margaret Atwood's image of snakes pouring themselves into darkness. (1989: 26). Here again, the verb chosen, pour, likens the snakes' smooth movement to that of a liquid. But this time, the reflexive form suggests that the snakes are actively performing the act of 'pouring.' One might say that either the vehicle or the tenor (the snakes, or the liquid they are supposed to resemble) are being 'personified'; but although this is indeed an interesting feature of the trope, it would seem to miss the point to spend time trying to isolate 'personification' from 'metaphor' in cases like this. 
linked. For instance, like forms tend to express comparisons between two concrete entities (the fabric was like rough sandpaper). But the linkings are not ironclad, and thus individual authors have much room for choice, as our example texts will show.

We will first give an overview of metaphorical usage, based on text selections about 50 pages long from each of fourteen authors from widely divergent genres and periods. It readily becomes clear that even a few features, taken together, go a long way toward identifying distinctive 'metaphorical styles' for these writers. We then go on to examine, briefly but in closer detail, the semantic patterns used by one modern novelist, Arundhati Roy. Finally, we suggest ways in which further research could elaborate on what we have done here.

\section{Methodological Dilemmas}

We constructed a database by simply identifying as many metaphors in each text as came to consciousness in one careful reading, and working with these as a basis for analysis. Of course, this method is necessarily imprecise, and the occasional oversight is inevitable. More important, since it is sometimes virtually impossible to draw a clear boundary between deliberate metaphor and extended meaning, or even between metaphor and literal comparison, any counts we use as a basis for analysis have a necessarily subjective flavor.

A last disclaimer involves possible distortion due to the nature of the particular texts chosen. Differences in point of view, plot, genre, the use of dialog and other features may predispose the same author to use metaphor quite differently from one text to another. A full account of any author would have to take this variation into account.

\section{Metaphorical Style: An Overview}

The fourteen authors studied have been grouped into three rough categories, for the purpose of giving an approximate idea of relative frequency for metaphor in the fifty-page calculating windows. excerpts chosen. The categories are contemporary fiction, classics, and science fiction/ fantasy, and the counts given here represent the metaphors consciously identified for each selection. 


\begin{tabular}{l|c}
\hline 1. Group One & Metaphor Count \\
\hline a. Charles Dickens & 19 \\
\hline b. William Faulkner & 42 \\
\hline c. Thomas Hardy & 120 \\
\hline d. Ernest Hemingway & 12 \\
\hline e. Sinclair Lewis & 87 \\
\hline f. Oscar Wilde & 91 \\
\hline
\end{tabular}

\begin{tabular}{l|l}
\hline 2. Group Two & MetaphorCount \\
\hline a. Margaret Atwood & 148 \\
\hline b. John Irving & 32 \\
\hline c. Allison Lurie & 36 \\
\hline d. Isaac Bashevis Singer & 46 \\
\hline
\end{tabular}

\begin{tabular}{l|l}
\hline 3. Group Three & Metaphor Count \\
\hline a. Isaac Asimov & 22 \\
\hline b. Arthur C. Clarke & 6 \\
\hline c. Ursula LeGuin & 48 \\
\hline d. Paul Levinson & 18 \\
\hline
\end{tabular}

Surprisingly enough, even this cursory overview count yields intriguing hints of unique patterns. For instance, given a high figure for metaphorical density in a text, and given no other information, we could reasonably hypothesize that we are not dealing with a science fiction piece. We could not date our passage, since contemporary writers do not seem to use more or fewer metaphors than their earlier counterparts. However, we could narrow our search for authorial identity to writers like Atwood, Hardy and Wilde, excluding many who seem to use metaphor more sparingly.

Another rough preliminary count relates to what we have called 'clustering.' Does a given metaphor group with others in the same paragraph, either performing the same function, setting forth a similar linkage, or at least contributing to a common effect in the text? Looking at our examples in this light yields a rather more nuanced set of distinctions, but nonetheless a set from which we can hypothesize a little further. 


\begin{tabular}{l|l}
\hline 4. Group One & Cluster Pattern \\
\hline a. Charles Dickens & $5 / 19(26 \%)$ \\
\hline b. William Faulkner & $28 / 42(67 \%)$ \\
\hline c. Thomas Hardy & $76 / 120(63 \%)$ \\
\hline d. Ernest Hemingway & $0 / 12(0 \%)$ \\
\hline e. Sinclair Lewis & $32 / 87(37 \%)$ \\
\hline f. Oscar Wilde & $62 / 91(68 \%)$ \\
\hline
\end{tabular}

\begin{tabular}{l|l}
\hline 5 Group Two & Cluster Pattern \\
\hline a. Margaret Atwood & $98 / 148(66 \%)$ \\
\hline b. John Irving & $15 / 32(47 \%)$ \\
\hline c. Allison Lurie & $16 / 36(44 \%)$ \\
\hline d. Isaac Bashevis Singer & $20 / 46(43 \%)$ \\
\hline
\end{tabular}

\begin{tabular}{l|l}
\hline 6. Group Three & Cluster Pattern \\
\hline a. Isaac Asimov & $11 / 22(50 \%)$ \\
\hline b. Arthur C. Clarke & $0 / 6(0 \%)$ \\
\hline c. Ursula LeGuin & $30 / 48(63 \%)$ \\
\hline d. Paul Levinson & $12 / 18(67 \%)$ \\
\hline
\end{tabular}

Interestingly, our three frequent users (Hardy and Atwood, followed by Wilde) also tend to 'link' their metaphors, or at least to produce them in groups, at about the same rate, i.e. about two-thirds of the time. Faulkner's relative clustering index falls within the same range, though of course his overall count is lower. Ursula LeGuin seems to reflect grouping and usage tendencies similar to Faulkner's; however, a quick look at her text from a qualitative standpoint shows that it is skewed by the existence of a single passage, stretching over several pages, in which a dragon makes a sudden appearance. At that stage, after long avoidance, LeGuin produces a remarkable stretch of eighteen metaphors in rapid succession, showing us the dragon's iron-dark body, wings as red as fire, rust-black scales, thorny tail, mailed flanks, and scythe-blade talons, and letting us hear a whisper of steel over steel from the creature's powerful wings (LeGuin 1991: 40-41). 
Before going on, it is worth noting places where our survey yields a textual landscape poor in metaphors. It is surprising, for instance, that Charles Dickens, whose writings have been admired by generations of readers, should be seen as having an almost spare metaphorical style. In fact, there seems to be a reason for this: Dickens' language is rich in other, potentially compensatory, imaginative uses of language, such as plays on words and humor or sarcasm. An example of conjunction used humorously occurs when Nicholas Nickleby's rather unsympathetic uncle Ralph refers to the protagonist as My nephew Nicholas, hot from school, with everything he learnt there fermenting in his head, and nothing fermenting in his pocket (Dickens 1993: 38). Likewise Hemingway, a predictable low-scorer on metaphor, uses dialog and repetition liberally, if not exuberantly, in his otherwise Spartan style. Few authors would consider producing a single sentence, as he does (Hemingway 1995: 37-38) containing no less than twenty instances of the word and!

John Irving, beloved of many for his imaginative, even outlandish, plot details, is yet another infrequent user of metaphor. At first, this is puzzling. But once again, there is a counterbalancing feature - this time, in his narrative style, which exhibits its own kind of imaginative comparison. In fact, Irving's text is practically bursting at the seams with pairings. One perceptive reader suggested to us that Irving may be 'literalizing' metaphors, as when he introduces an armless Native American legend, and later an armadillo, as symbols. But more strikingly, Irving's entire narrative structure displays a dizzying array of twosomes on every level. He seems almost unable to give us a new character or plot detail without introducing a counterfoil. The narrator has two contrasting 'best friends,' and his mother has two equally contrast-worthy men in her life. The grandmother is mistaken for her maid, their house for a local inn. When the narrator changes religions due to an initiative of his father's, Owen Meany does just the same. The two boys' mothers are contrasted at length, as are their educational careers. And the list goes on. In the passage considered for this paper, although only 32 metaphors appear, about 50 of these plot or character comparisons keep the reader as actively engaged as any string of metaphors could do.

A similar explanation may apply to the relatively low frequency and high degree of clustering in our science fiction/fantasy texts. Perhaps here, too, the plot itself fulfills the need for imaginative pairings. Unlike Irving, 
these authors do not constantly work doublets into their plots. However, the plots themselves invite the reader to create them. Asimov's and Clarke's stories involve human experience with distant planets; LeGuin's takes place in a fantasy world - and Levinson's is split between a distant prehistoric era and a whimsical present-day version of Pennsylvania where fireflies have been genetically engineered by Amish-like people as a tool for arson. With worlds like these, so removed from everyday experience, the reader is constantly called upon to shuttle between the reality of the world around her and the very different universe of the story. Perhaps for this reason, if only unconsciously, writers in these genres may feel little need to incorporate metaphor into their literary style. The relatively high percentage of clustering in these texts (cf. LeGuin's dragon passage) also suggests a pattern: the science fiction writer may generally avoid metaphor - however, the need will suddenly arise every so often when something shows up which is unusual even to the beings of the imagined story world: a dragon for LeGuin, a new kind of robot for Asimov. At this point, a rich flood of metaphor can be called into service to remind the reader that, even in this strange world, things can be unexpected enough to require analogy to be understood.

\section{Individual Choices and the Patterns They Create}

Before moving on, suppose we try to imagine just one metaphorical choice: the one Ursula LeGuin made when she settled on the phrase scytheblade talons for her dragon. First, she presumably had to decide that she wanted to express a physical trait of the dragon's claws, namely their sharpness - ittedly linked to abstractions about power and fierceness. Given that goal, she had a number of different forms available to her, which range from those of traditional literary tropes ( $7 a$ and $7 b$ ) to a simple noun phrase (7e) whose literal meaning the reader is left to fill in. These and two others are listed in (7):

(7) a. The talons were scythe-blades (traditional metaphor)

b. The talons (were) like scythe-blades (traditional simile)

c. The talons were as sharp as scythe-blades (as-Adjective-as Noun Phrase)

d. The creature's talons, (sharp) scythe blades which... (NP appositive)

e. Fearsome scythe-blades cut the air....(NP) 
In fact, LeGuin opts for none of these. Instead, she often chooses to place a modifier in the position just before the noun. In fact, her eighteen metaphors for the dragon fall into a rather idiosyncratic distribution, with this kind of 'premodifier' dominating the description:

(8) Ursula LeGuin's dragon metaphors:
a. Premodifiers ( $\mathrm{N}$ or Adj): 11 (iron-dark body, p. 41; rust-dark mail, p. 42) ${ }^{2}$
b. $\mathrm{N}(\mathrm{P})$ of NP: 4 (a whisper of steel sliding over steel, p. 42)
c. Adjective appositive: 1 (hot, furnace-hot, p. 44)
d. As Adj as NP: 1 (wings as red as fire, p. 41)
e. NP : 1 (sword-thorn, repeated twice, pp. 42, 43)
f. Like: 1 (a voice like the dry roar of a kiln-fire, p. 43)

The standard like form, possibly the most transparent or typical option, appears only once; likewise its cousin form, as $A d j$ as $N P$, also appears only once. The description is instead carried largely by the relatively uncommon prenominal modifier, which is absent from about half the other passages surveyed. It seems reasonable to suggest that this may be a trademark of LeGuin's writing. The runner-up, the $N(P)$ of $N P$ form, is likewise a relatively uncommon form. In noting this simple pattern, we have already taken a first step toward sketching this author's 'metaphorical style,' even though this text holds few examples to generalize from. In fact, the next writer, who is relatively more prolific in the metaphor domain, seems to share LeGuin's preference for this otherwise uncommon premodifier form.

\subsection{Sinclair Lewis and the Prenominal Modifier}

Sinclair Lewis occasionally opts for the most popular, canonical like form, as when he shows us an old woman whose toothless mouth shuts like a mud-turtle's, and whose hair he paints as yellow like moldy linen (Lewis 1948: 25). But the examples in (9) rank him as a frequent user of prenoun position as well:

\footnotetext{
2 Since we refer to only one possible text per author, examples for a given author will usually be identified, as here, only by page reference in parenthes rather than repeating the year in each parenthetical citation.
} 
(9) a. ....a girl stood in relief against the cornflower blue of Northern sky. (Lewis 1948: p. 7)

b. Every cell of her body was alive-thin wrists, quince-blossom skin, ingenue eyes, black hair. (p. 8)

c. ...her only near relative was a vanilla-flavored sister... (p. 9)

d. She had the impression that all the men had coarse voices, large damp hands, toothbrush mustaches, bald spots, and Masonic watch charms. (p. 32)

e. His wife had bleached cheeks, bleached hair, bleached voice and a bleached manner. (p. 46)

f. The Dawsons and Mr. Mott teetered upon weary feet, and smiled at Carol with crystallized expressions. (p. 47)

In fact, the 19 pre-nominal examples found represent a substantial portion (nearly a quarter) of all metaphors in the Main Street excerpt. Given that this form does not even show up in selections by many of our other authors, it seems fair to hypothesize that it may count as a stylistic trademark for Lewis.

In the category of meaning, it is worth noting that over half of Lewis' metaphors can be seen as expressing a relationship between the physical features of two entities (color, texture, visual appearance) for one of two purposes: either to provide a neutral description, as when he evokes the image of a corn-colored woman (42); or to imply some characteristic that goes beyond physical description, as when he compares the women and buildings of Gopher Prairie to lap-dogs and grocery boxes respectively, with the intention of suggesting subservience and dullness in the women, boring lack of originality in the structures:

\footnotetext{
(10) a. ...women who after much expenditure of labor and bad temper still grotesquely resemble their own flatulent lap-dogs (p. 29)

b. gaunt frame shelters like grocery boxes...(p. 31)
}

Sinclair Lewis also embeds a relatively high proportion of personifications in his text; our list contains fourteen, many of these implied by a prenoun modifier. Thus, he refers in one place to a smug Pullman (p. 24); in another, he calls the sunshine dizzy and the sky resolutely blue (p. 29). In other examples, he invokes a lugubrious bay-window (p. 33), competent one-story brick and cement buildings (p. 39), and the grasping prairie (p. 37). 


\subsection{Hardy: Personification, Allusion, and Reality Levels}

Like Lewis, Hardy indulges in frequent personification - though his cases cluster more stubbornly around a single theme, as when he speaks of Egdon Heath in terms that suggest it participates in actions, has feelings and engages in relationships:

(11) The sombre stretch of rounds and hollows seemed to rise and meet the evening gloom in pure sympathy, the heath exhaling darkness as rapidly as the heavens precipitated it.... When other things sank brooding to sleep the heath appeared slowly to awake and listen. Every night its Titanic form seemed to await something... Then Egdon was aroused to reciprocity; for the storm as its lover, and the wind its friend. (Hardy 1995: 32)

But several other features identify this author more precisely. Hardy stands out most visibly in our little mini-corpus as unique for the particularly rich stock of allusions that appear in his writing. It should come as no surprise that a relatively high proportion of his metaphors are expressed via allusion, sometimes in the form of premodifiers, as when Egdon Heath is called an Ishmaelitish thing with an expectant Titanic form (33); or when the features of the heath's occupants are said to be drawn with Dureresque vigour and dash (p. 41).

Metaphorical allusions, of course, can take a variety of syntactic forms. Hardy uses the relatively uncommon, canonical be type metaphor when he compares the fires on the heath to the priestesses of Bacchus, with their wild, disheveled appearance: Some were Maenades, with winy faces and blown hair (p. 40).

In another characteristic choice, Hardy tends to provide not one, but a whole complex of metaphors in rapid succession. If allusions are also involved in such a passage, we can be reasonably confident that we are dealing with Hardy, at least in comparison to the other authors in our sample. In the rather contorted example given here, the underlying message seems to be that ordinary places like Iceland and Scheveningen can offer attractions that are more lasting or more enticing to some travelers than the more conventional pleasures offered by other places like Heidelberg and Baden. 
(12) And ultimately, to the commonest tourist, spots like Iceland may become what the vineyards and myrtle-gardens of South Europe are to him now; and Heidelberg and Baden be passed unheeded as he hastens from the Alps to the sanddunes of Scheveningen. (p. 32)

Finally, one notes in Hardy's examples something that we call, for want of a better term, a mix of reality levels. At times, a physical entity is compared with a relative abstraction, as when the narrator says, The heath down there was now a vast abyss... (p. 40).

Sometimes, a real entity described in the novel is compared with some other kind of 'unreal' figure, for instance from the distant past. Here, groups of people on the heath are likened to people from some forgotten age:

(13) It was as if these men and boys had suddenly dived into past ages, and fetched therefrom an hour and deed which had before been familiar with this spot. (p. 40)

Earlier, a lone figure had received similar treatment:

(14) The first instinct of an imaginative stranger might have been to suppose it the person of one of the Celts who built the barrow, so far had all of modern date withdrawn from the scene. It seemed a sort of last man among them, musing for a moment before dropping into eternal night with the rest of his race. (p. 38)

In another kind of reality mix, Hardy compares a dying fire to the eyes of a sort of fantasy creation of his own imagination, namely, the 'corpse of day':

(15) She ascended to her old position at the top, where the red coals of the perishing fire greeted her like living eyes in the corpse of day. (p. 70)

He seems to combine the two (reference to the past and to a sort of whimsical or fantastic image) in yet another example, where he likens the sound of the autumn wind to the ruins of human song which remain to the throat of fourscore and ten (p. 71). 


\subsection{Wilde: The Phrasal Metaphor}

At first sight, it is difficult to see one particular trait as emerging from the brief excerpt chosen for Oscar Wilde. His usage seems to span a wide range of form and meaning types. However, this diversity is itself a valid characteristic; moreover, on closer inspection, some subtle features do emerge. For one thing, Wilde seems to use variants of the be-form more than any other author in our sample; the 16 be/become examples in his text represent quite a large proportion, given that the form is rare in the other authors considered. Examples include Lord Henry's unflattering description of Lady Brandon as being a peacock in everything but beauty (Wilde 1983: 9). Or again, when Lord Henry speaks disparagingly of one who allows another to influence him:

(16) "His virtues are not real to him. His sins, if there are such things as sins, are borrowed. He becomes an echo of someone else's music, an actor of a part that has not been written for him..." (p. 20)

Yet another straightforward be appears when the same rather outspoken character compares vice to color, saying that (s) in is the only real color element left in modern life (p. 31).

In terms of form, we may tentatively suggest that Wilde favors what could be called 'phrasal' metaphors, where the imagined comparison is implied simply by a phrasal category such as noun phrase or verb phrase. Thus, according to Lord Henry again, beauty is implicitly likened to a royal person, in that it has its divine right of sovereignty, and makes princes of those who have it. (p. 24).

This last extended passage from Wilde, where Lord Henry is described as 'performing' for the benefit of Dorian Gray, contains an almost dizzying series of metaphors, many of which are expressed in a sequence of verb phrases.

(17) He played with the idea, and grew willful; tossed it into the air and transformed it; let it escape and recaptured it; made it iridescent with fancy, and winged it with paradox. The praise of folly, as he went on, soared into a philosophy, and Philosophy herself became young, and catching the mad music of Pleasure, wearing, one might fancy, her wine-stained robe and wreath of ivy, danced like a Bacchante over the hills of 
life, and mocked the slow Silenus for being sober. Facts fled before her like frightened forest things. Her white feet trod the huge press at which wise Omar sits, till the seething grape juice rose round her bare limbs in waves of purple bubbles, or crawled in red foam over the vat's black, dripping, sloping sides. It was an extraordinary improvisation. (pp. 43-44)

\subsection{Atwood: Appositives and the Serial Metaphor}

A great deal could be said of Margaret Atwood's use of metaphor in terms of meaning categories and function. However, two formal features are particularly striking in her text: appositives and serial form.

First, one gets a pervasive feel of appositive structures as a preferred carrier for metaphorical meaning in the Atwood text. Well over a third of all her metaphors are either in straightforward appositive form, or else are part of a larger appositive construction:

(18) a. Cordelia sits with nonchalance,... staring blankly at the other people with her gray-green eyes, opaque and glinting as metal. (Atwood 1989: 4)

b. Our mouths are tough, crayon-red, shiny as nails. (p. 4)

c. $[\mathrm{T}] \mathrm{h}$ he newspapers had pictures of children in iron lungs...

These pictures, the iron lung a cylinder, a gigantic sausage roll of metal... fascinated me (p. 7)

In fact, the appositive 'feel' to Atwood's style is greatly enhanced by other features of her writing, and even becomes dominant when we think of these other features. For instance, even when she uses a simple like form, it tends to be set off with commas, suggesting pseudo-appositive status for these prepositional phrases that could have fit quite comfortably into the syntax of the sentence:

(19) a. It's evening, one of those gray watercolor washes, like liquid dust, the city comes up with in fall. (p. 8)

b. A disembodied voice, an angel voice, wafting through the air. If I died this minute it would go on like that, placid and helpful, like an electronic afterlife. (p. 43)

c. That's home, I told myself. That's where you really live. Among all that stagey scenery, too beautiful, like a cardboard movie backdrop. (p. 43) 
d. Last night I felt the approach of nothing. Not too close but on its way, like a wingbeat, like the cooling of the wind, the slight initial tug of an undertow. (p. 43)

In fact, this last example hints at the next feature, which we have called Atwood's penchant for 'serial metaphor.' Time and again, rather than settle for one metaphor, she gives a whole series of images, implied or explicit, letting the reader play with them or choose from among them at will. Examples couched in NP form appear here in (20):

(20) a. There's blood, a taste I remember. It tastes of orange Popsicles, penny gumballs, red licorice, gnawed hair, dirty ice. (p. 9)

b. This is the middle of my life. I think of it as a place, like the middle of a river, the middle of a bridge, halfway across, halfway over. (p. 13)

In (21a), a series of adjectives implying personified windows stands alone as a fragment. In (21b), various not-quite-parallel fragments suggest multiple metaphors for the narrator's sense of alienation:

(21) a. Underneath the flourish and ostentation is the old city, street after street of thick red brick houses, with ... their watchful, calculating windows. Malicious, grudging, vindictive, implacable. (p. 14)

b. But since coming back here I don't feel weightier. I feel lighter, as if I'm shedding matter, losing molecules, calcium from my bones, cells from my blood; as if I'm shrinking, as if I'm filling with cold air, or gently falling snow. (p. 13)

Finally, although we have not looked in detail at function, it is difficult to pass over Atwood without noting that one is quite often tempted to simply label the purpose of a given Atwood metaphor as simply 'lyricism.' A good illustration comes from the passage in (22), in which the narrator is talking about her childhood experience of watching the family ears on trips in the car:

(22) My father's... are large and soft looking, with long lobes; they're like the ears of gnomes, or those of the flesh-colored, doglike minor characters in Mickey Mouse comic books. My mother... her ears... They're narrow, with fragile upper edges, like the handles of china cups, although she herself is not fragile. My brother's ears are round like dried apricots or like the ears of the green-tinged, oval-headed aliens from outer space he draws with his colored pencils. (pp. 22-23) 
One would be hard put to justify an extended discussion of the family ears on the grounds that it supports plot, or that it deepens the reader's psychological portrait of the family members. At best, it might be said to help us see the narrator's early penchant for her adult calling as a creative artist. Still, its main contribution to the text seems to be to amuse and delight, rather than to perform some more mundane narrative task.

\subsection{Lurie: The Metaphor Explained}

Allison Lurie uses a wide variety of syntactic forms for her metaphors in the text examined. Nearly all contrast two concrete beings, either to elaborate some visual trait, or to imply a deeper characteristic, such as the gaiety of children and the cautious mystery of feline grace in (23):

(23) a. [S]and sparkled like Christmas tinsel in the sun... Streets and shops and restaurants were crowded with adults dressed like children at play, in colorful shorts, T-shirts, sneakers, and sandals. Their garb was the outward sign that for these few days or weeks they were free to enjoy and indulge themselves, like kids on vacation. (Lurie 1999: 22)

b. "She told him....," Jacko volunteered from the porch railing, where he had assumed a graceful, watchful pose which echoed that of his cat. ( p. 34)

In fact, such animal comparisons as these seem to be a favorite with Lurie. But the trait that makes her metaphorical style stand out most, one which is already hinted at in the two cases above, seems to be her tendency to explain metaphors - or alternately, to deliberately choose metaphors that need explanation to be understood as she intends. These two animalhuman metaphors describing her hapless character Wilkie's marital mishaps would hardly make an impression without the author's guide to what they are meant to convey:

(24) a. He had been married twice... First to a sweet and graceful but totally impractical girl whom he compared to a highbred Persian cat ("all cashmere fur and huge sky-blue eyes and special diet, but she always had a slight cold, couldn't bike more than a mile without collapsing, and was terrified of most other animals"). (pp. 4-5) 
b. Then, on the rebound, he had married a young woman who was equally good looking and much more competent and robust ("strong and healthy as an Alaskan busky"), but who turned out to be deeply hostile to men and especially to Wilkie. For example, when at a time of crisis he asked her to retype one of his articles, the busky hot only growled at him but dropped his manuscript into the kitchen wastebasket...(p. 5)

Yet another dog comes in when the author introduces the character Molly Hopkins. Again, the author goes beyond mere mention of the dogs, as she cues us to the specific features that Molly shares with them:

(25) As she aged, she bore a greater and greater resemblance to the Hopkinses' long series of Maltese terriers - especially the last one, Lulu, whose death three months ago still devastated her whenever she recalled it. Molly had the same big brown eyes, pug nose, mildly eager expression, and sparse floppy white curls. (p. 25)

About a third of Lurie's metaphors are explained, some of them extensively. To give only one further example, her character Dr. Wilkie engages in a gloomy reflection on his life, comparing his career to what a weatherman does on a televised broadcast. The basic metaphor might be said to be contained in the simple statement, That's what I'm doing now, where that refers to the weatherman's actions and what I'm doing now to Wilkie's. But the rest of the passage is needed as explanation if the reader is to comprehend the substance of Wilkie's depressed thoughts:

(26) Wilkie... recalled a recent interview in a local TV studio where he had learned that what one sees on the screen is a like a construct: there is no real map projected behind the weatherman, only a blank wall toward which he gestures. That's what I'm doing now, he had thought at the time, gesturing at a blank wall, while people imagine I see something there. (p. 20)

As the animal examples suggest, Lurie seems also to extend and interweave the metaphors in her text. A particularly long-lived metaphor occurs when Molly's view of death is likened to a dinosaur, which in turn is likened to an image on a rubber stamp. The image stretches over much of two pages (pp. 30-31), and is taken up again a few pages later. In the process, the dinosaur is given backup, turning into a whole company or battalion of creatures who are characterized as stupid, greedy, and so inept that they sometimes drop their victims (Molly's imagined idea of a near-fatal 
illness or accident). In fact, Molly herself has been 'dropped,' and as a result has a series of physical defects to cope with. The long passage ends with Molly's alternation in her feelings toward the dinosaurs, whom she is occasionally ready to welcome, although she usually wants them to stay away a little longer, because the world was full of things she didn't want to miss (p. 31).

Although Lurie's metaphor count seems relatively modest, her extensions and explanations tend to make metaphorical images more salient in her text than a simple count would reveal.

\subsection{Singer and the Psychological State Metaphor}

Turning to Isaac Bashevis Singer, we find an author whose style favors two related form/meaning links. Over half of Singer's metaphors fall into one of two form types: one schematized as the $N(P)$ of $N(P)$; and another in which two sentences or verb phrases are joined by as if. In both cases, the strong tendency is for these forms to suggest that the behavior of a character reflects some inner disposition or character trait. Both forms show up in the description of the character Luria's demeanor when he is about to invite his wife's lover into their home:

(27) ... his face wore the heavy expression of a man who swallows an offense and knows something others do not. He walked with his feet spread wide and the ungainliness of someone who no longer needs to please....The invitation was uttered boldly, from deep within his chest, as though he had suddenly overcome all buman weaknesses. (Singer 1999: 32)

As the scene continues, Luria produces the key to the flat, his yellow eyes gleaming with the satisfaction of someone acting to spite himself (p. 34). A little later, the offending lover Grein's inner conflict of conscience is personified as a trickster, a mutineer who did the opposite of what he ordered. (p. 39). Finally, the feelings of Anna, the wife, are again cast in the $N$ of $N P$ form (as in 28a), and later in a form that might best be called a variant of as if (29b):

(28) a. Anna came up to him, her eyes burning with anger and the passion of someone in the heat of an argument. (p. 42)

b. She stared at him quizzically, the way one does at anyone who impedes the progress of a public conveyance. (p. 43) 
As they flee, the couple's guilt is reflected in yet another as if form; they move mechanically, almost as if they were two gangsters on their way to commit a long-planned crime together (p. 45). By this time, even the inanimate has been called into service to support the mood of the scene, since Luria's home has been portrayed as permeated by the silence of a public place abruptly emptied after a day of tumult and bustle and now left to itself (p. 33). This overview is far from comprehensive. However, it shows the feasibility of identifying unique metaphorical styles all the more convincingly for its brevity. Surely, if distinctive styles can be identified from a relatively small sample and with a limited number of features, a more fine-grained analysis can only yield more subtle results.

\section{A Closer Look: Arundhati Roy and The God of Small Things}

Finally, moving on from overview mode, we undertake to analyze a set of metaphors in a complete novel text, looking more closely for meanings, common themes, and insights into the relationship between metaphor and plot or theme. The text is Arundhati Roy's The God of Small Things (1997). As with the novelists in our broad survey, it is possible at the outset to make a clear statement about what seem to be Roy's preferred forms: nearly one-third of the novel's metaphors use the traditional like, as, as if, and as though forms, and many of these appear in sentence fragments.

A concentrated look at this extended work suggests that these 'simpler' forms may contribute to establishing a tone of simplicity, innocence, and spontaneity, as the narrative point of view is largely that of children twins who struggle to cope with guilt and grief after they are persuaded to believe that they have murdered their cousin, Sophie Mol, and are coerced to implicate their mother's forbidden lover in the incident.

Many of the like/as forms link the plot to simple, concrete images that would be readily available to a child. For instance, a description of an old man includes this passage: 
(29) He oiled himself with warm, peppered coconut oil, kneading his old, loose flesh that stretched willingly of his bones like chewing gum (Roy 1997: 15)

Similarly, in a description of a minor character, Kochu Maria, the woman's earrings look to one of the twins like gleeful children in a merry-go(not all the way) round. (p. 162). The deity invoked in the title is also described in childlike terms: So Small God laughed a hollow laugh, and skipped away cheerfully. Like a rich boy in shorts (p. 20).

Several metaphors scattered throughout the novel bear semantic features that hint at the agony suffered by the children and other characters: these include what have termed 'circus,' 'leash,' 'bubble,' and 'vomit' metaphors, all of which suggest control and suffering. A second consistent web of metaphors revolves around images for the contrasting themes of silence and speech, foreshadowing the eventual mutism of one twin at the end of the story.

The manipulative great-aunt, known as Baby Kochamma, is linked to metaphors of control from the circus and leash class: Like a lion tamer, she tamed twisting vines and nurtured bristling cacti (p. 27). When she neglects a vine, it grows knotted and withered like a circus whose animals had forgotten their tricks (p. 27). Baby Kochamma's scheming plans grow more serious when she manipulates her grieving nephew in order to remove unwanted family members from the house, here expressed in the traditional be form: Chacko breaking down doors was only the sad bull thrashing at the end of Baby Kochamma's leash (p. 305).

The young twin Rahel is also described through the control of a leash:

(30) So, the redsteps once again. This time Rahel lagging. Slow. No I don't want to go. A ton of bricks on a leash. (p. 106)

Later, the image is manipulated, suggesting the child's powerless acquiescence:

(31) Rahel held by Ammu's hand. A mosquito on a leash (p. 284)

Perhaps one of the most moving episodes of the narrative involves the final steps of Velutha, the forbidden lover of the twins' mother, an 
Untouchable who becomes the scapegoat in Baby Kochamma's cover-up. The as though fragment cited in (32) provides a sense of Velutha's resignation, and once again uses the leash theme:

(32) His feet walked him to the river. As though they were the leash and he was the dog. (p. 272)

In a departure from the like forms but retaining the effect of sentence fragments, the novel includes several references to the fragility of bubbles and the expulsion of vomit, some of which refer to Estha, the twin who tries to contain his guilt with silence: Estha carried them home in the crowded tram. A quiet bubble on a sea of noise (p. 13). Bubbles refer both to suffering silent twins in (33) as well:

(33) The jam was still hot and on its sticky scarlet surface, pink froth was dying slowly. Little banana bubbles drowning deep in jam and nobody to belp them. (p. 185)

The location of much of the story's devastation, called the History House, is also described in terms of liquid, silence, and fragile bubbles, in an image that makes a subtle link to the vomit metaphor, since it treats the bubbles as belonging to imagined bodily fluids in the house:

(34) Like sunken treasure dredged up from the ocean bed. Whale-kissed and barnacled. Swaddled in silence. Breathing bubbles through its broken windows. (p. 291)

Estha's bubbles of silent agony are briefly expelled when he tries to vomit: Estha convulsed but nothing came. Just thoughts. And they floated out and floated back in (p. 103). Estha's literal nausea contains his emotional sickness in this passage:

(35) He vomited a clear, bitter, lemony, sparkling, fizzy liquid. The acrid aftertaste of a Little Man's first encounter with Fear. (p. 113)

Metaphors of sickness also describe the despair of Velutha when he realizes the horror of his fate:

(36) Though the rain washed Mammachi's spit off his face, it didn't stop the feeling that somebody had lifted off his head and vomited into his body. Lumpy vomit dribbling 
down his insides. Over his heart. His lungs. The slow thick trip into the pit of his stomach. All his organs awash in vomit. (p. 270)

The cluster of 'silence' metaphors begins early in the novel. After Estha is made to believe that he murdered his cousin and is forced to incriminate Velutha in the incident, the silence that holds the boy hostage is personified in a lengthy cluster of metaphors that includes a speech-sucking octopus that leaves Estha numb:

(37) Once the quietness arrived, it stayed and spread in Estha. It reached out of his head and enfolded him in its swampy arms. It rocked him to the rhythm of an ancient, fetal heartbeat. It sent its stealthy, suckered tentacles inching along the insides of his skull, hoovering the knolls and dells of his memory, dislodging old sentences, whisking them off the tip of his tongue. It stripped his thoughts of the words that described them and left them pared and naked. Unspeakable. Numb. (p. 13).

This view of silence as a suffocating animal remains with Estha as he grows to manhood: He grew accustomed to the uneasy octopus that lived inside bim and squirted its inky tranquilizer on bis past. Gradually the reason for his silence was hidden away, entombed somewhere deep in the soothing folds of the fact of it. (p. 13)

As the metaphor clustering continues, the source of Estha's agony, his solitary word that wrongfully blames Velutha, is revealed:

(38) The word Estha's octopus couldn't get at: Yes [author's italics]. Hoovering didn't seem to help. It was lodged there, deep inside some fold or furrow like a mango hair between molars. That couldn't be worried loose. (p. 32)

The addition of the mango metaphor strengthens the image of Estha's guilt as something tangible that is permanently embedded in his mind. These clustered passages suggest that different metaphors work to produce a single idea within a larger metaphorical framework.

Silence continues to control, not just Estha, but also other members of his family after his Uncle Chacko scolds the twins' mother, Ammu: Silence filled the car like a saturated sponge. 'Washed-up' cut like a knife through a soft thing... this was the trouble with families. Like invidious doctors, they just knew where it burt (p. 68). Later, as they sleep in the History House where 
they are hiding, Esthappen and Rahel wake to the tumult as the sleeping Velutha is attacked by the police): Screams (die) in them and (float) belly up, like dead fish (p. 292), as the twins instinctively resort to silence while their friend is brutally beaten nearby.

Further metaphors compare silence to a bruise (p. 189), and to a culinary 'secret' later in the same scene: $A$ red, tender-mango-shaped secret in a vat ( $\mathrm{p}$. 191). Velutha's eventual death at the hands of the brutal police advances the same idea of something mysterious and unrevealed: Blood spilled from bis skull like a secret (p. 303). As Estha is taken to identify the dying Velutha as the perpetrator, his sibling experiences the small procession as a manifestation of silence: Rabel alone watched them walk down the corridor like silent but substantial ghosts (p. 109). This comparison of Estha to a silent ghost anticipates the final word Rahel's brother utters-Yes-which transforms him into a mute shell of a child. When Estha answers the inspector's question with the word that condemns Velutha, the child's young life is irretrievably changed: Childhood tiptoed out. Silence slid in like a bolt (p. 303). Silence is also expressed abstractly as a feature of the adult Estha's bedroom: Silence bung in the air like secret loss (p. 87).

Metaphors of silence and secrecy are countered by like/as metaphors of voices and written words, which further advance the fear of the twins, who wish to suppress what they believe to be the truth of their own guilt. At Sophie Mol's funeral, the church swells like a throat with the sound of sad singing (p. 6), and later like a throat with voices (p. 8). In contrast, Estha grows silent as though he had simply run out of conversation and had nothing left to say (p. 12). In another passage, the temperament of the scheming Baby Kochamma, who masterminds Velutha's tragic fate, is described as having the character of a writing instrument, here seen as a vehicle of destruction: In the days that followed, Baby Kochamma focused all her fury at her public bumiliation on Velutha. She sharpened it like a pencil (p. 78). The young Rahel is also compared to a pen in this innocent like metaphor: Rabel's new teeth were waiting inside her gums, like words in a pen (p. 37). In a link to the metaphors of silence, Rahel's words never emerge from her pen: after Estha is exiled to his father's far-away home, Rahel never (writes) to him. There are things you can't do - like writing letters to a part of yourself. To your feet or hair. Or beart (p. 156). These metaphors confirm that, while speech remains with other characters, Estha and Rahel are silenced by the horrifying events of their shared childhood. 
The like/as metaphors of silence and secrecy are endorsed by metaphors of futility, which confirm the fruitlessness of words and action for the twins, their mother, and her lover, Velutha. In a passage that brings to mind Baby Kochamma's support of Indian taboos, a practice that contributes to the novel's tragedy, the destruction of thought and expression is compared to the frequent death of insects:

(39) Strange insects appeared like ideas in the evenings and burned themselves on Baby Kochamma's dim forty-watt bulbs. (p. 11)

In another allusion to futility, the twins' mother, Ammu, wonders at the absurdly lavish attire she wore at her ill-fated wedding, thinking of her appearance in the marriage costume as being like polished firewood ( $\mathrm{p}$. 43). Ammu also unwittingly foretells her children's bleak future when she thinks of them as like a pair of small bewildered frogs, engrossed in each other's company, lolloping arm in arm down a highway full of hurtling traffic. Entirely oblivious to what trucks can do to frogs (p. 42). Another metaphor of futility contains a reference to the hopeless lives of the Untouchables who become Christians - and therefore casteless but ostracized. The passage, which defines the paradox of their plight, features a like metaphor extended to a fragment that features a verb of oppression:

(40) It was a little like having to sweep away your footprints without a broom. Or worse, not being allowed to leave footprints at all. (p. 71)

After Estha unwillingly implicates Velutha, an Untouchable, in the disaster, the young twin is sent to live with his father in another region of India, where he ponders the emptiness of realizing that a few hours can change a whole lifetime:

(41) ...those few dozen hours, like the salvaged remains of a burned house - the charred clock, the signed photograph, the scorched furniture - must be resurrected from the ruins and examines. Preserved. Accounted for. (p. 32)

In a final example of futility, once again expressed in like metaphors, the decay of the family business car symbolizes the destruction of the Kochamma family: 
(42) With every monsoon, the old car settled more firmly into the ground. Like an angular, arthritic hen settling stiffly on ber clutch of eggs. With no intention of every getting up. The PARADISE PICKLES \& PRESERVES signboard rotted and fell inward like a collapsed crown. (p. 280)

A study of the semantics of metaphor, particularly the predominant like form in The God of Small Things, demonstrates another contribution of metaphor to narrative fiction, in its ability to provide cohesion. In a story told out of sequence-the plot continually moves back and forth over 23 years-the simple like metaphors of a child's naïve world view connect the narrative's themes to an otherwise disjointed story line. Metaphors that link the characters' lives to circus animals, leashed creatures, fragile bubbles, and toxic vomit reinforce the pervading sense that the story unfolds through the perspective of vulnerable, suffering children who draw comparisons from a child's experiences as they struggle to cope with the loss of their own innocence. Likewise, the metaphors that express silence and secrecy point toward those of futility, as the silence of the victimized characters directs them to resignation to their plight. In short, these simple like forms hold the narrative together: their frequent presence serves as a reminder that children tell this story of a tragedy that they do not understand-and that the reader might not appreciate fully without the constant emergence of these simple but profound metaphors

\section{Conclusion}

Metaphor has always fascinated literary scholars, and with the emergence of frameworks such as cognitive linguistics, it has become possible to explore that fascination with increasingly finely honed tools (see, e.g., Kittay 1987; Turner 1991; Gibbs \& Steen 1990). Our study is an attempt to contribute to the growing insights coming to light in this context. We have tried to sketch the rudiments of a technique for identifying 'metaphorical style,' using examples from fifteen authors and based largely on frequency, clustering, meaning and form. Of course, what we have done here represents only a partial picture. A comprehensive classification would include features only occasionally brought into the present study. These include the functions of metaphor, the point of view of any given metaphor, and its status as explicit or implied, as well as the nature of the interrelationships and extensions it takes part in. 
Other studies on metaphorical style would ask more narrowly focused questions than we have addressed here. What is the relationship between creative and 'everyday' metaphor in a given text? How do different authors treat be or like metaphors in terms of meaning or function? Again, such fine-grained analyses would ultimately need to draw on the processing, psycholinguistic, and philosophical factors which have been elaborated in the past few decades, in a growing literature on the nature and comprehension of metaphor (e.g. Gibbs \& Steen 1997, Kittay 1987, Steen 1994, Sacks 1978, Turner 1991). The possibilities are at least as numerous as the forms, meanings, and functions hinted at in this paper. We have not tried to present definitive answers; in fact, I think it is fair to say we join lovers of literature everywhere in hoping there may be no 'final word' to be said on linguistic creativity.

E-mail: jfontaine@city-net.com Recebido em novembro de 2002 Aprovado em outrubro de 2003

\section{REFERENCES ${ }^{3}$}

Asimov, Isaac. 1983. The Robots of Dawn. New York: Ballantine Books: 1-50. Atwood, Margaret. 1989. Cat's Eye. New York: Bantam Books: 3-55.

Cameron, Lynne, \& Graham Low (Eds.) 1999. Researching and Applying Metaphor. New York: Cambridge University Press.

Clarke, Arthur C. 1986. The Songs of Distant Earth. New York: Ballantine Books: 3-66.

Dickens, Charles. 1993. Nicholas Nickleby. London: Everyman's Library: $1-50$.

DonnA, Jeannine. 2002, July. The Grammar of Metaphor. Paper presented at the Association for the Teaching of English Grammar Summer Conference Fishkill, N. Y.

FAUlKner, William. 1932-1985. Light in August. New York: Vintage Books: 3-52.

Foster, Don. 2000. Author Unknown: On the Trail of Anonymous. New York: Henry Holt and Company.

3 References used as a basis for data collection are marked for the page range covered; for instance, Isaac Asimov's text was scanned for examples occurring from page 1 to page 50. 
GibBs, Raymond W., Jr., \& Gerard SteEN (Eds.) 1990. Metaphor in Cognitive Linguistics. Amsterdam: John Benjamins.

Hardy, Thomas. 1995. The Return of the Native. London: Pan Books: 31-81. Hemingway, Ernest. 1995. A Farewell to Arms. New York: Simon \& Schuster: 3-54.

Inving, John. 1989. A Prayer for Owen Meany. New York: Ballantine Books: $1-58$.

JaCKendoff, Ray. 2002. Foundations of Language. Oxford: Oxford University Press.

KitTAY, Eva Feder. 1987. Metaphor: Its Cognitive Force and Linguistic Structure. Oxford: Clarendon Press.

Lakoff, George, \& Mark Johnson. 1983. Metaphors We Live By. Chicago: University of Chicago Press. , \& Mark Turner. 1989. More than Cool Reason: A Field Guide to Poetic Metaphor. Chicago: University of Chicago Press.

LeGuin, Ursula. 1991. Tehanu: The Last Book of Earthsea. New York: Bantam Books: 1-50.

Levinson, Paul. 1999. The Silk Code. New York: Tor: 20-70.

LEwIS, Sinclair. 1948. Main Street. New York: Harcourt, Brace \& World: 7-56.

Lurie, Alison. 1999. The Last Resort. New York: Henry Holt and Company: 3-54.

Meyer, Michael. 1999. The Bedford Introduction to Literature: Reading, Thinking, Writing. Boston: St. Martin's Press.

Roberts, D. 2001, September. Don Foster Has a Way with Words. Smithsonian 32.6: 101-111.

Roy, Arundhati. 1997. The God of Small Things. New York: HarperCollins. SACKs, Sheldon, Ed. 1979. On Metaphor. Chicago: University of Chicago Press.

Singer, Isaac Bashevis. 1999. Shadows on the Hudson. New York: Plume: 3-51. STEEN, Gerard. 994. Understanding Metaphor in Literature. London: Longman. Turner, Mark. 1991. Reading Minds: The Study of English in the Age of Cognitive Science. Princeton, N. J.: Princeton University Press.

Wilde, Oscar. 1983. The Picture of Dorian Gray. Mahwah, New Jersey: Watermill Press: 3-50. 